\title{
Anion recognition in water by charge-neutral halogen and chalcogen bonding foldamer receptors
}

\author{
Arseni Borissov, ${ }^{\dagger}$ Igor Marques, ${ }^{\ddagger}$ Jason Y. C. Lim, ${ }^{\dagger}$ Vítor Félix, ${ }^{\ddagger}$ Martin D. Smith, ${ }^{\dagger}$ and Paul D. Beer*,† \\ †Chemistry Research Laboratory, Department of Chemistry, University of Oxford, Mansfield Road, Oxford OX1 3TA, \\ U.K. \\ ‡Department of Chemistry, CICECO - Aveiro Institute of Materials, University of Aveiro, 3810-193 Aveiro, Portugal \\ KEYWORDS Halogen bonding, chalcogen bonding, anion recognition, foldamer
}

\begin{abstract}
A novel strategy for the recognition of anions in water using charge-neutral $\sigma$-hole halogen bonding and chalcogen bonding acyclic hosts is demonstrated for the first time. Exploiting the intrinsic hydrophobicity of halogen and chalcogen bond donor atoms integrated into a foldamer structural molecular framework containing hydrophilic functionalities, a series of water-soluble receptors were constructed for anion recognition investigation. Isothermal titration calorimetry (ITC) binding studies with a range of anions revealed the receptors to display very strong and selective binding of large, weakly hydrated anions such as $\mathrm{I}^{-}$and $\mathrm{ReO}_{4}^{-}$. This is achieved through the formation of 2:1 host-guest stoichiometric complex assemblies, resulting in an encapsulated anion stabilized by cooperative, multidentate convergent $\sigma$-hole donors, as shown by molecular dynamics simulations carried out in water. Importantly, the combination of multiple $\sigma$-hole-anion interactions and hydrophobic collapse results in $I^{-}$affinities in water that exceed all known $\sigma$-hole receptors, including cationic systems $\left(\beta_{2}\right.$ up to $\left.1.68 \times 10^{11} \mathrm{M}^{-2}\right)$. Furthermore, the anion binding affinities and selectivity trends of the first example of an all-chalcogen bonding anion receptor in pure water are compared with halogen bonding and hydrogen bonding receptor analogues. These results further advance and establish halogen and chalcogen bond donor functions as new tools for overcoming the challenging goal of anion recognition in pure water.
\end{abstract}

\section{INTRODUCTION}

One of the key challenges in modern anion supramolecular chemistry is the recognition of anions in water, which needs to be achieved for applications in biology, healthcare, and environmental monitoring under aqueous conditions to be realised. To date, an overwhelming majority of reported abiotic anion receptors operate in organic solvents, whose lower polarity compared with water facilitates anion coordination via non-covalent interactions such as hydrogen bonding (HB) and anion- $\pi$ interactions. ${ }^{1}$ In water, recognition of anions is thwarted by their strong hydration, resulting in an additional energetic barrier due to desolvation during host-guest binding. Early examples of anion binding in water were dominated by highly charged polycationic receptors to enhance the electrostatic attraction with anions. ${ }^{2-8}$ More recent years have offered alternative strategies, such as the formation of strong coordinate bonds with Lewis acidic main group elements (e.g. Sb), ${ }^{9,10}$ transition metals, ${ }^{11-14}$ and lanthanides. ${ }^{15-17}$ Counterintuitively, low charge or neutral receptors have also recently been demonstrated to be capable of functioning in aqueous media. ${ }^{18}$ Notable rare examples that operate in $100 \%$ water include cyclopeptide macrocycles, ${ }^{19,20}$ bambus[6] urils, ${ }^{21,22}$ biotin[6] urils, ${ }^{23,24}$ and indolocarbazoles $^{25}$ where hydrogen bonding and hydrophobic effects contribute to the preferential recognition of weakly hydrated chaotropic anions (e.g. $\mathrm{PF}_{6}^{-}, \mathrm{SCN}^{-}, \mathrm{ClO}_{4}^{-}$).
The applications of $\sigma$-hole interactions such as halogen bonding $(\mathrm{XB})$ and chalcogen bonding $(\mathrm{ChB})$, the attractive supramolecular interactions between heavy electrondeficient Group 17/16 atoms and Lewis bases ${ }^{26,27}$ are important recent developments in the field. Compared to $\mathrm{HB}$, these interactions are characterised by more stringent directionality, greater hydrophobicity, and are less sensitive to solvent and $\mathrm{pH}$ changes. ${ }^{28-30}$ Recent advances in the use of $\mathrm{XB}$ and $\mathrm{ChB}^{28,31}$ include several types of anion receptors, ${ }^{32-35}$ self-assembled structures, ${ }^{36-39}$ and transmembrane anion transporters. ${ }^{40-43}$ Applications in aqueous solution are however extremely rare and based exclusively on cationic receptors. These include the observation of helicate complexes between I- and iodopyridinium receptors $^{44,45}$ as well as our work on achieving anion recognition in water for $\mathrm{XB}^{46-48}$ and aqueous-organic media for $\mathrm{ChB}^{49}$ using macrocyclic and mechanically interlocked hosts. Most importantly, these $\sigma$-hole donor hosts often outperform $\mathrm{HB}$ host analogues in binding affinities and offer greatly contrasting anion selectivity. Nonetheless, the resulting anion affinities still pale in comparison to natural biotic receptors.

Herein, we present a novel strategy for aqueous anion binding by $\sigma$-hole donor hosts, which capitalises on the tendency of $\mathrm{XB}$ and $\mathrm{ChB}$ donor atoms (I/Te) to selfassemble in water due to their intrinsic hydrophobicity. Confinement of these hydrophobic functions within a shielded core of a folded receptor can create a stabilised 
anion binding cavity with multiple $\sigma$-holes directed in a convergent manner. This process, which drives the folding of peptides into complex tertiary and quaternary structures, has successfully been exploited by Flood and coworkers, who used a preorganised aryl-triazole HB foldamer receptor to bind $\mathrm{Cl}^{-}$and $\mathrm{H}_{2} \mathrm{PO}_{4}^{-}$in $1: 1 \mathrm{MeCN} / \mathrm{H}_{2} \mathrm{O}$ solution via $\mathrm{C}-\mathrm{H}$ hydrogen bond donors in a dehydrated microenvironment. ${ }^{50,51}$ By combining the strict geometric control of $\sigma$-hole interactions with receptor folding via hydrophobic collapse, we present the first-ever series of chargeneutral XB and ChB receptors (Figure 1) capable of very strong and highly selective $\mathrm{I}^{-}$binding in pure water. Reinforced by the tendency of hydrophobic $\sigma$-hole donors to converge, the resulting I- affinities surpass all known cationic XB receptors, even exceeding the $\mathrm{I}^{-}$affinity of the natural $\mathrm{Na}^{+} / \mathrm{I}^{-}$symporter (NIS) protein in $\mathrm{Na}^{+}$-bound form. ${ }^{52}$ Furthermore, the first example of an all-ChB anion receptor studied in pure water allows direct anion binding affinity and selectivity trend comparison with XB and HB receptor analogues.

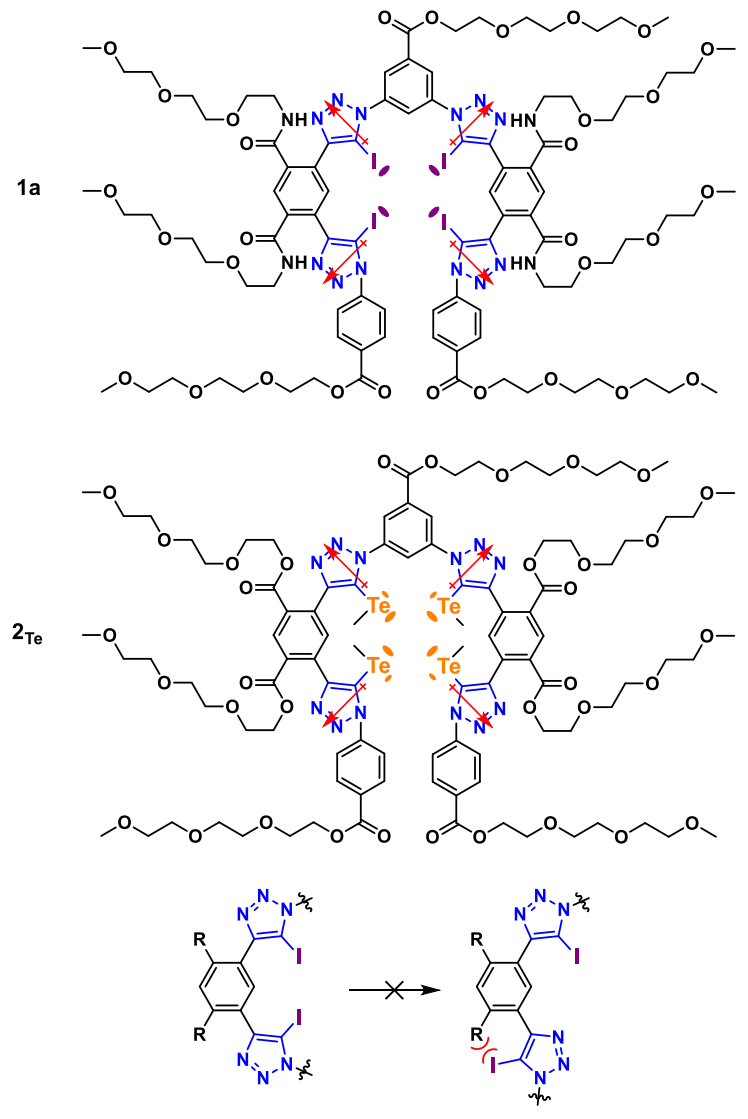

Figure 1. Structures of $\mathrm{XB}$ and $\mathrm{ChB}$ anion receptors described in this work. Local dipoles of the triazole units and positions of $\sigma$-holes are highlighted. Bottom: Preorganisation of receptor arms by restricted intramolecular rotation.

\section{RESULTS AND DISCUSSION}

\section{Receptor design and synthesis}

Building upon our previous work on tetradentate iodotriazole XB receptors, ${ }^{53}$ we designed a foldamer structure consisting of alternating 5-iodo- or 5-methyltellanyl triazoles and 1,3-phenylene units, whilst carrying several amide- or ester-bound tri(ethylene glycol) groups to impart water solubility (Figure 1). Positioning of solubilising groups ortho to the I/MeTe-triazoles sterically restricts the relative rotation of triazole and phenylene units. As the bulky I or Te atoms cannot move past the ortho substituent, arms of the receptor are preorganised towards a folded state which is favourable for anion binding. The host molecules are also clearly differentiated into a hydrophilic outer rim and a hydrophobic interior to stabilise folded conformations that contain a central cavity lined with $\sigma$-hole donors. Groups at the termini of the receptor can be varied (Scheme 1) to customise the binding and sensing properties. For instance, the appendage of 4-aminonaphthaleneimide fluorophores to the XB receptor scaffold enabled significant 'turn on' fluorescent I'- sensing (vide infra).

The tetrakis(iodotriazole) framework of the $\mathrm{XB}$ receptors 1a-d was assembled in a sequence of copper(I)-catalysed azide-alkyne cycloaddition (CuAAC) reactions (Scheme 1). ${ }^{54}$ First, azide terminal synthon $\mathbf{5 a , c , d}$ was reacted with bis(iodoethynyl) precursor 7 in a statistical reaction leading to the arm fragment $\mathbf{3}$. In the case of the azide $\mathbf{5 b}$, the steric bulk of its naphthaleneimide unit prevented it from reacting with 7 under the usual CuAAC conditions. The target iodotriazole $\mathbf{3 b}$ was instead synthesized from $\mathbf{5 b}$ and $\mathbf{6}$ in a one-pot desilylation-cycloaddition-iodination procedure (See ESI for details). In this method the cycloaddition occurs between the azide and $\mathrm{Cu}$ alkynide, thus circumventing the steric restrictions. Arm fragments 3a-d were then joined with the bis(azide) core synthon $\mathbf{8}$. Finally, the resulting precursors $4 \mathbf{a}-\mathbf{d}$ were treated with the primary amine $\mathbf{9}$. This provided the final products $\mathbf{1 a - d}$ via amidation of the labile ethylparaben esters in 4a-d. Following TMS-deprotection of $\mathbf{6}$, a similar sequence of $\mathrm{Cu}$ AAC and amidation steps provided the HB analog 1a $\mathbf{a}_{\mathbf{H}}$ Introduction of tri(ethylene glycol) amide groups in the last step avoids the terminal iodination of alkynes in the vicinity of amides, which tends to provide cyclized products instead of the desired iodoalkynes. ${ }^{55,56}$ Additionally, this alleviates the purification difficulties common for heavily PEGsubstituted compounds.

The water-soluble $\mathrm{ChB}$ anion receptor $\mathbf{2}_{\mathrm{Te}}$ was derived from bis(methyltellanylethynyl) precursor $\mathbf{1 1}_{\mathrm{Te}}$ in two CuAAC steps ${ }^{57}$ analogous to the synthesis of $\mathbf{1 a - d}$ (Scheme 2). To prepare $\mathbf{1 1}_{\mathrm{Te}}$, a transmetallation between $\mathrm{Ag}$ alkynide and $\mathrm{MeTeBr}^{58}$ was performed, which formed $\mathbf{1 1}_{\mathrm{Te}}$ under very mild conditions and in high yield. To the best of our knowledge this is an entirely new method to access organotellanyl alkynes. In $\mathbf{2}_{\text {Te }}$ an all-ester scaffold was used, replacing the amide linkers present in 1a-d with ester groups. This was due to synthetic difficulties which prevented clean amidation of ethylparaben esters in the presence of 5-(methyltellanyl) triazoles as well as formation of MeTe-alkynes in the vicinity of amides. 
Scheme 1. Synthesis of XB anion receptors $1 \mathrm{a}-\mathrm{d}$ and the $\mathrm{HB}$ analog $1 \mathrm{a}_{\mathrm{H}}$
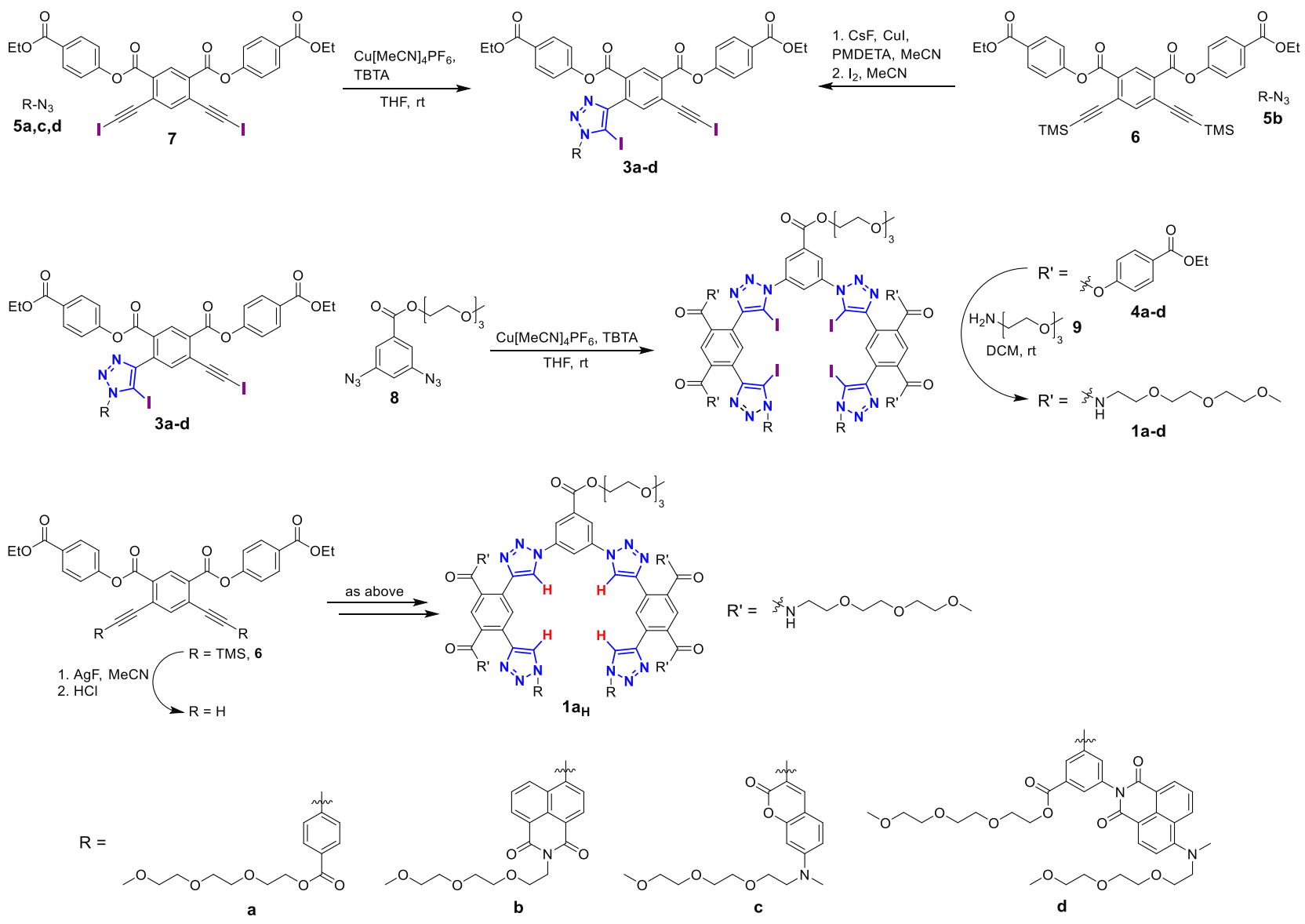

Scheme 2. Synthesis of tri(ethylene glycol) ester-substituted bis(methyltellanylethynyl) and bis(iodoethynyl) precursors $11_{\mathrm{Te}}$ and $11_{\mathrm{I}}$ that allow to access the $\mathrm{ChB}$ anion receptor $2_{\mathrm{Te}}$ and its $\mathrm{XB}$ analog $\mathrm{2}_{\mathrm{I}}$ via CuAAC sequences similar to that shown in Scheme 1.

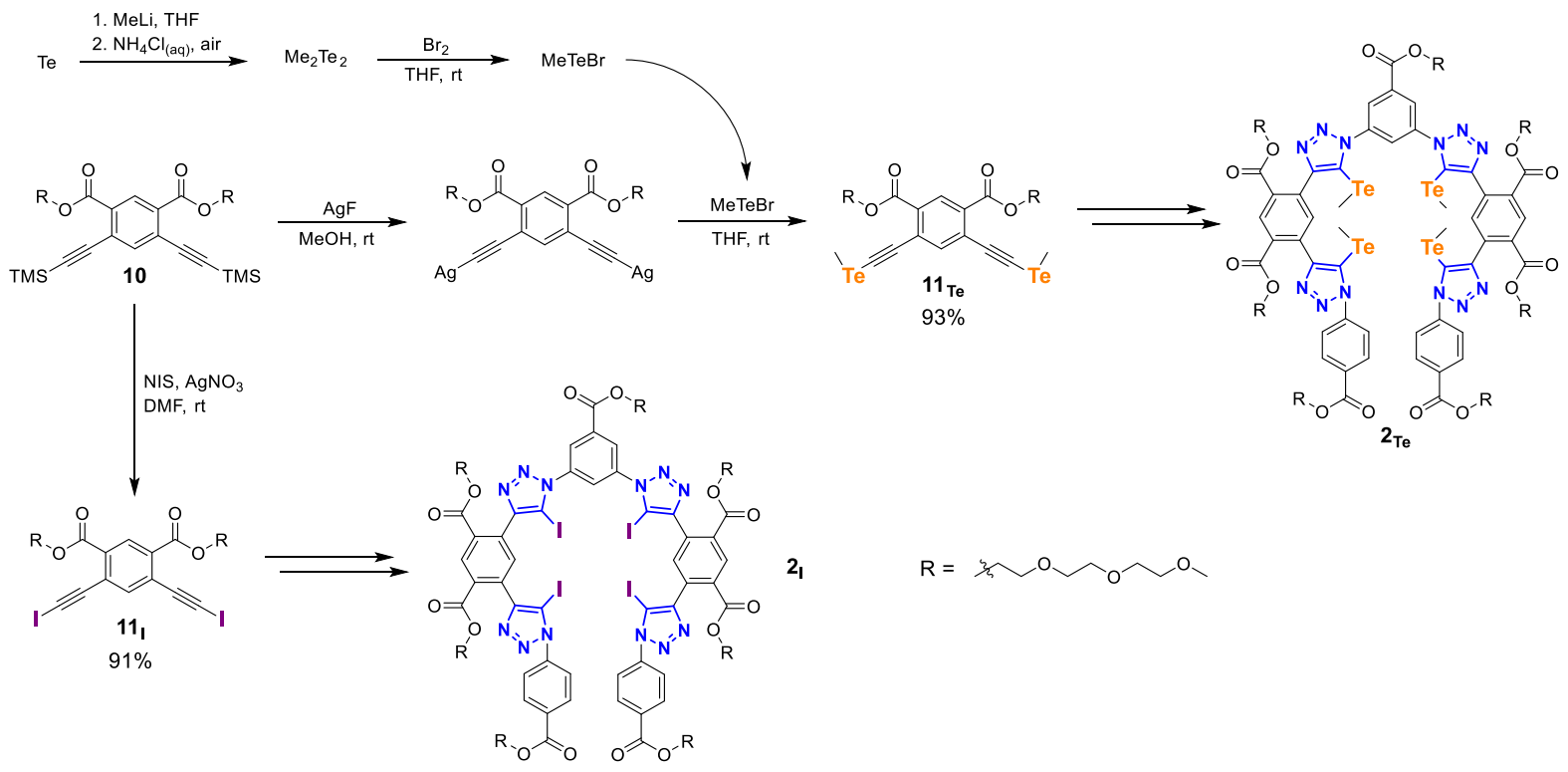

To attain a precise comparison between $\mathrm{ChB}$ and $\mathrm{XB}$ anion receptors, an all-ester XB compound $2_{I}$ was also prepared via an analogous route. As the all-ester backbone is less hydrophilic than the ester-amide type present in 1a-d, receptors $\mathbf{2}_{\mathrm{Te}}$ and $\mathbf{2}_{\mathrm{I}}$ displayed much lower water solubili- ty. Interestingly, their solubility sharply decreased with increasing temperature. This effect can be attributed to the transition of tri(ethylene glycol) chains from $\mathrm{C}-\mathrm{C}$ gauche to the less hydrophilic anti conformation. ${ }^{59,60}$ 

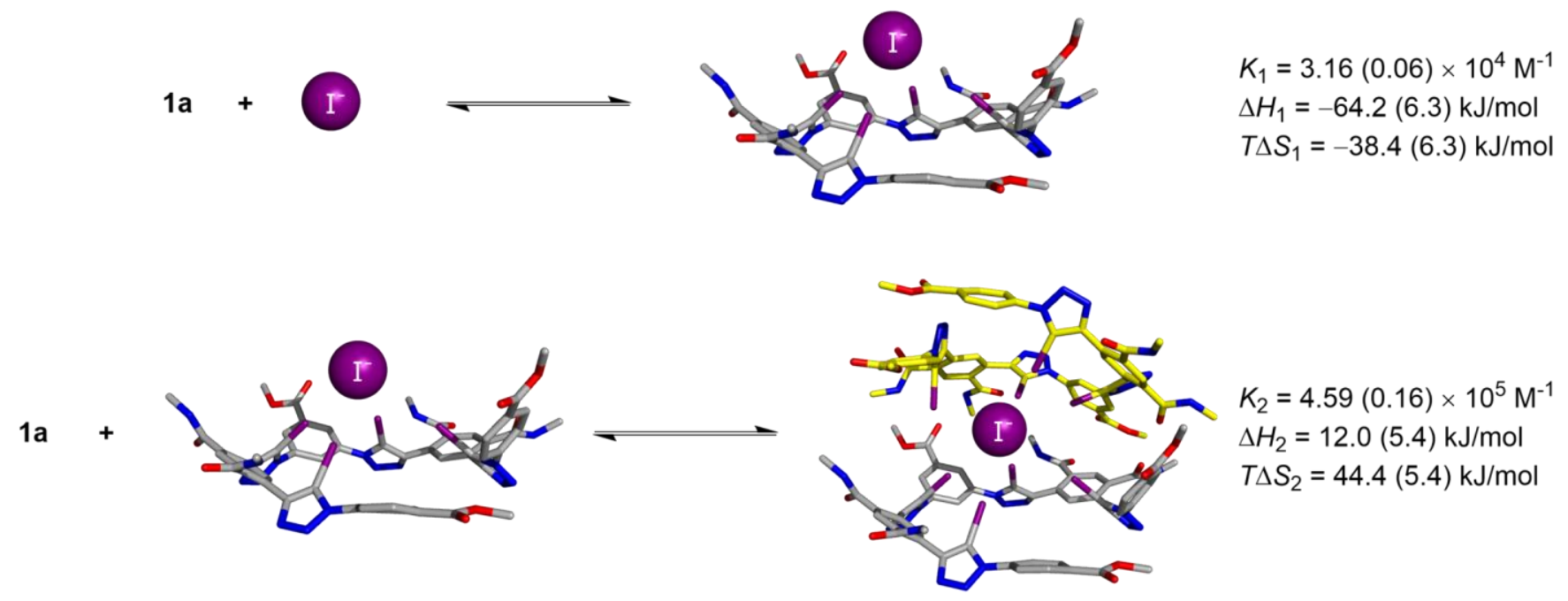

Figure 2. Equilibria and thermodynamic signatures of stepwise 2:1 binding between $\mathbf{1 a}$ and I-. The receptor model is shown with truncated solubilising chains.

Table 1. Equilibria and thermodynamics of $I^{-}$binding by XB anion receptors $1 \mathrm{a}-\mathrm{d}$ and $\mathrm{2}_{\mathrm{I}}$, ChB receptor $\mathbf{2}_{\mathrm{Te}}$, and $\mathrm{HB}$ receptor $1 \mathrm{a}$ as determined in water by ITC.

\begin{tabular}{cccccc}
\hline & $\boldsymbol{\beta}_{\mathbf{2}}[\mathbf{M}]^{-\mathbf{2}}$ & $\boldsymbol{K}_{\mathbf{1}}\left[\mathbf{M}^{-\mathbf{1}}\right]$ & $\boldsymbol{K}_{\mathbf{2}}\left[\mathbf{M}^{-\mathbf{1}}\right]$ & $\boldsymbol{\Delta H}[\mathbf{k J} / \mathbf{m o l}]$ & $\boldsymbol{T} \boldsymbol{S}[\mathbf{k J} / \mathbf{m o l}]$ \\
\hline $\mathbf{1 a}$ & $1.45(0.04) \times 10^{10}$ & $3.16(0.06) \times 10^{4}$ & $4.59(0.16) \times 10^{5}$ & $-52.2(1.0)$ & $5.9(1.0)$ \\
$\mathbf{1 b}$ & $8.68(2.18) \times 10^{9}$ & $1.60(0.37) \times 10^{4}$ & $5.54(1.32) \times 10^{5}$ & $-38.3(2.1)$ & $18.4(2.7)$ \\
$\mathbf{1 c}$ & $1.68(0.14) \times 10^{11}$ & $4.77(0.40) \times 10^{4}$ & $3.53(0.24) \times 10^{6}$ & $-55.3(0.9)$ & $8.8(1.0)$ \\
$\mathbf{1 d}$ & $7.47(0.57) \times 10^{6}$ & $4.87(0.52) \times 10^{3}$ & $1.54(0.11) \times 10^{3}$ & $-52.5(1.8)$ & $-13.3(1.6)$ \\
$\mathbf{2}_{\mathbf{T e}}$ & $2.64(0.05) \times 10^{7}$ & $3.67(0.41) \times 10^{2}$ & $7.30(1.00) \times 10^{4}$ & $-31.6(2.3)$ & $10.1(2.2)$ \\
$\mathbf{2}_{\mathbf{I}}$ & $7.28(0.57) \times 10^{9}$ & $2.87(0.08) \times 10^{2}$ & $2.54(0.22) \times 10^{7}$ & $-34.6(1.4)$ & $20.8(1.6)$ \\
$\mathbf{1 a}_{\mathbf{H}}$ & $---a$ & $3.88(0.02) \times 10^{3}$ & --- a & $-23.2(0.1)$ & $2.7(0.1)$ \\
\hline
\end{tabular}

Uncertainties are given in parentheses. All experiments were performed in unbuffered water and I- was introduced as NaI. Titrations were done at $298 \mathrm{~K}$ for $\mathbf{1 a}-\mathbf{d}$ and $\mathbf{1} \mathbf{a}_{\mathbf{H}}$, or at $293 \mathrm{~K}$ for $\mathbf{2}_{\mathrm{Te}}$ and $\mathbf{2}_{\mathbf{I}}$ a $1: 1$ binding stoichiometry.

\section{Anion binding studies}

The anion binding properties of all receptors $\mathbf{1 a - d}, \mathbf{1} \mathbf{a}_{\mathbf{H}}$ $\mathbf{2}_{\text {Te }}, 2_{\text {I }}$ were investigated in water by ITC. All experiments with 1a-d and $\mathbf{1} \mathbf{a}_{\mathbf{H}}$ were performed at $298 \mathrm{~K}$, while $\mathbf{2}_{\mathbf{I}}$ and $\mathbf{2}_{\text {Te }}$ were studied at $293 \mathrm{~K}$ due to their higher solubility at lower temperature (See section S3, ESI for full details).

ITC experiments revealed binding in 2:1 receptor-anion stoichiometry for $\mathbf{1 a - d}, \mathbf{2}_{\mathrm{I}}$ and $\mathbf{2}_{\mathrm{Te}}$ with I- (Table 1, Figure 2 ), the same was observed in titrations of $\mathbf{1 a}$ and $\mathbf{2}_{\mathrm{Te}}$ with other anions (Table 2). In contrast, the HB receptor $\mathbf{1} \mathbf{a}_{\mathrm{H}}$ was found to bind exclusively in 1:1 stoichiometry. This can be explained by the differences in steric bulk of HB and $\sigma$-hole donor atoms. In the case of $\mathbf{1} \mathbf{a}_{\mathbf{H}}$, the anion guest can be bound in the plane of the folded receptor backbone in a similar fashion to the known triazolophane ${ }^{61,62}$ and foldamer ${ }^{63,64}$ examples. In $\mathrm{XB}$ and $\mathrm{ChB}$ receptors, the very large size of convergent I or MeTe units sterically forces the coordinated anion to be held above the plane of the receptor. This results in a capped binding geometry as we have previously observed in the solid state structure of a tetradentate receptor $\mathrm{NaI}$ complex, ${ }^{53}$ which facilitates coordination of a second receptor molecule to the anion. Additionally, hydrophobic character of the $\sigma$-hole donor atoms can be expected to augment the hydrophobicity of phenylenetriazole backbone and favour aggregation in water. Molecular dynamics simulation of 2:1 complex of $\mathbf{1 a}$ and I- (vide infra) shows this structure to be stable in aqueous solution. Further evidence for the 2:1 binding mode was obtained by diffusion-ordered NMR (DOSY) which showed a decrease in diffusion coefficients upon guest addition where significant 2:1 binding was indicated by ITC (see section S4, ESI for more details).

The ITC binding data for all receptors with $\mathrm{I}^{-}$in water are collected in Table 1. XB receptors 1a-d displayed very high I- affinity, with 2:1 cumulative association constants $\left(\beta_{2}\right)$ up to $1.68 \times 10^{11} \mathrm{M}^{-2}$ in the case of $1 \mathrm{c}$. $K_{2}$ was $1-2$ orders of magnitude higher than $K_{1}$ in 1a-c, indicating a strong preference for 2:1 binding. In 1d $K_{2}$ was of much lower magnitude, which is likely due to the large size of its termini sterically disfavouring the formation of the 2:1 stoichiometric complex. Although the all-ester XB receptor 2 I displayed a similar $\beta_{2}$ value to $\mathbf{1 a}$, its binding was much more dominated by $K_{2}$. This may be attributed to the all-ester outer rim of $2_{\text {I }}$ being relatively less hydrophilic than the mixed ester-amide functionalities of $\mathbf{1 a}$. This can be expected to disfavour the folding of $\mathbf{2}_{\mathbf{I}}$ into $1: 1$ binding conformation 
but enhance the hydrophobic collapse into a 2:1 complex. Additionally, higher entropic contribution in $\mathbf{2}_{\mathbf{I}}$ and $\mathbf{2}_{\mathrm{Te}}$ can be explained by the release of water molecules weakly interacting with their ester groups. It is especially noteworthy that all $\sigma$-hole-donor receptors exhibit higher iodide binding affinity than the $\mathrm{Na}^{+} / \mathrm{I}^{-}$symporter protein (NIS, $K_{\mathrm{a}}=4.46 \times 10^{4} \mathrm{M}^{-1}$ ) responsible for the uptake of $\mathrm{I}^{-}$ into the follicular cells of the thyroid gland in the first step of the thyroid hormone biosynthesis. ${ }^{52}$

In all $\mathrm{XB}$ and $\mathrm{ChB}$ receptors $\mathrm{I}^{-}$binding was mainly enthalpy-driven with overall $\Delta H$ of $2: 1$ binding in the range of -30 to $-55 \mathrm{~kJ} / \mathrm{mol}$ and generally favourable but less dominant entropic contributions. The strong exothermicity may be attributed to two effects: the ability of the $\sigma$-hole donors to form strong $\mathrm{XB} / \mathrm{ChB}$ interactions with $\mathrm{I}^{-}$within the largely dehydrated core of the host complex, as well as the formation of HB interactions between the released water molecules and the bulk solvent.

As shown in Figure 2 for 1a, the stepwise binding consists of enthalpy-driven formation of 1:1 complex followed by entropy-driven coordination of another receptor molecule. In the first binding event this highly exothermic signature is likely due to four strong halogen bonds being formed while the capped complex geometry allows $\mathrm{I}^{-}$to remain significantly hydrated. In the second equilibrium formation of new XB is probably less efficient (as shown by molecular modelling, at least six out of the eight iodotriazoles in 2:1 complex form XB contacts). This binding event must therefore be driven by favourable entropy change associated with nearly complete dehydration of $\mathrm{I}^{-}$and partial dehydration of the receptor molecules. Similar thermodynamic signatures were observed for $\mathbf{2}_{\mathrm{I}}$ and $\mathbf{2}_{\mathrm{Te}}$ (Table S3-1).

Amongst 1a-d, the unusually low enthalpic contribution seen for $\mathbf{1 b}$ is an indication that XB contacts from its outer iodotriazoles are disrupted by the steric bulk of its naphthaleneimide termini. At the same time, restricted rotation of these termini relative to the iodotriazoles is a likely explanation for the higher $T \Delta S$. In contrast, in $1 \mathbf{d}$ the I- binding is unusually entropically disfavoured, which may be attributed to the loss of additional degrees of freedom in its exceptionally large termini.

The ChB receptor $\mathbf{2}_{\mathrm{Te}}$ displayed a similar binding pattern to $2_{\text {I }}$ albeit with much lower $K_{2}$. This indicates that formation of $2: 1$ complex by $2_{\mathrm{Te}}$ is disfavoured by the additional steric bulk of Te-bound $\mathrm{CH}_{3}$ groups. As the $K_{1}$ and $\Delta H$ values are similar in $\mathbf{2}_{\mathrm{Te}}$ and $\mathbf{2}_{\mathrm{I}}$, it follows that the XB and ChB interactions with $\mathrm{I}^{-}$must be of comparable strength and enthalpically driven character. The involvement of ChB in I- coordination was confirmed by the large downfield changes in ${ }^{125} \mathrm{Te}$ chemical shifts $(\Delta \delta)$ upon titration with TBAI in $\mathrm{CD}_{3} \mathrm{CN}$ (Figure 3 ). In this organic solvent, $\mathbf{2}_{\mathrm{Te}}$ formed a 1:1 binding complex with $\mathrm{I}^{-}\left(K_{\mathrm{a}}=96.8 \pm 0.6 \mathrm{M}^{-1}\right)$. Combined with a smaller $\Delta \delta$ magnitude of outer Te atoms relative to the inner Te donors this implies that in $\mathrm{CD}_{3} \mathrm{CN}$ there is no solvophobic effect to drive the folding and 2:1 association of $2_{\mathrm{Te}}$. In water however, hydrophobic collapse stabilises the $1: 1$ and especially $2: 1$ bound states, prevailing over the weak solvation of $\mathrm{I}^{-}$.

Behaviour of $\mathbf{1} \mathbf{a}_{\mathbf{H}}$ is in stark contrast with its $\sigma$-hole counterparts. Its $1: 1 \mathrm{I}^{-}$binding constant is lower than $K_{1}$ of $\mathbf{1 a - d}$, indicating a significantly weaker interaction than in $\mathrm{XB}$ receptors and a size mismatch with $\mathrm{I}^{-}$. Due to its inability to form 2:1 complex (see DOSY data in section S4, ESI), 1ан has much lower overall I- affinity than any of the XB/ChB receptors. Similarly to the $\sigma$-hole receptors, $\mathbf{1} \mathbf{a}_{\mathbf{H}}$ displays enthalpy-dominated binding, ostensibly due to the formation of weak $\mathrm{C}-\mathrm{H}$ hydrogen bonding interactions with the bound $\mathrm{I}^{-}$akin to that observed by Flood and coworkers. ${ }^{50}$

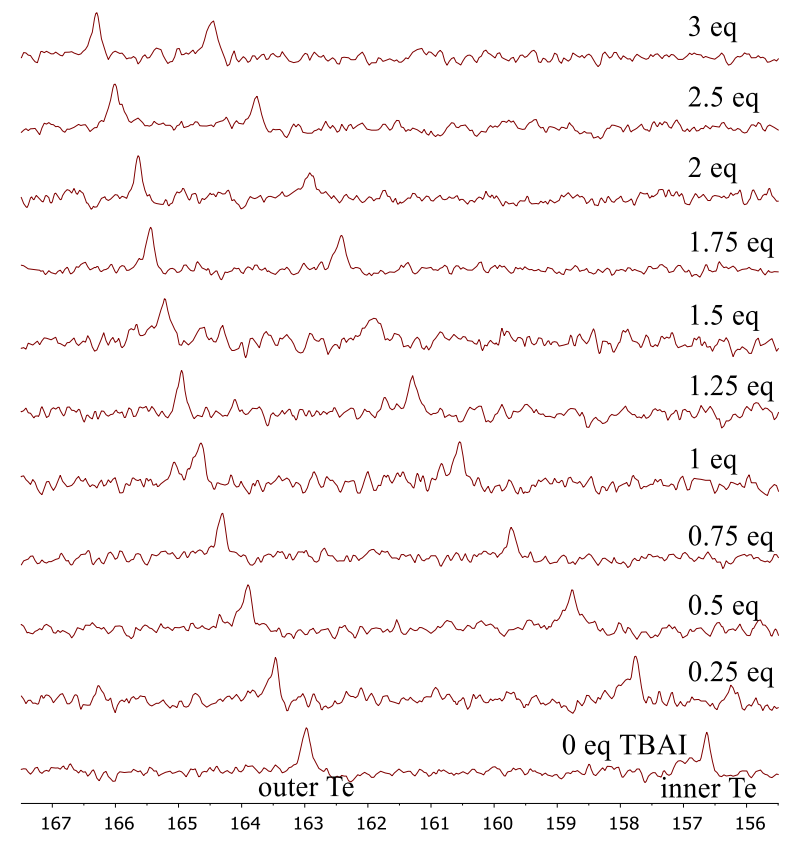

Figure 3 Changes of ${ }^{125} \mathrm{Te}$ chemical shifts of $\mathbf{2}_{\mathrm{Te}}(5 \mathrm{mM}$ in $\mathrm{CD}_{3} \mathrm{CN}, 298^{\circ} \mathrm{K}, 158 \mathrm{MHz}$ ) titrated with tetrabutylammonium iodide (TBAI).

The exceptionally strong I- binding by $\mathbf{1 a}$ and $\mathbf{2}_{\text {Te }}$ prompted us to investigate their affinities towards a range of other anions in water by ITC. As shown in Table 2, the $\sigma$-hole receptors $\mathbf{1 a}$ and $\mathbf{2}_{\mathrm{Te}}$ showed a general preference for binding weakly hydrated anions such as $\mathrm{SCN}^{-}$and $\mathrm{ReO}_{4}^{-}$in 2:1 stoichiometry resulting from the hydrophobic collapse. On the other hand, no measurable interaction was found with $\mathrm{ClO}_{3}{ }^{-}, \mathrm{NO}_{3}{ }^{-}, \mathrm{AcO}^{-}, \mathrm{H}_{2} \mathrm{PO}_{4}{ }^{-}$, and $\mathrm{SO}_{4}{ }^{2-}$. In 1 a high selectivity for I- $\left(\Delta H_{\text {hyd }}=-325 \mathrm{~kJ} / \mathrm{mol}\right)$ over SCN${ }^{-}$and $\mathrm{ClO}_{4}^{-}\left(\Delta H_{\text {hyd }}=\right.$ $-310,-229 \mathrm{~kJ} / \mathrm{mol}$, respectively) ${ }^{65}$ indicates that shape and size complementarity effects are present. Particularly, the isotropic spherical geometry of I- likely allows maximal interactions with the highly-directional $\sigma$-holes. Chalcogen bonding $\mathbf{2}_{\mathrm{Te}}$ was also $\mathrm{I}^{-}$selective, although the degree of discrimination over $\mathrm{SCN}^{-}$was less pronounced. This significant $\mathrm{I}^{-}$selectivity is in contrast to the known macrocyclic receptors with hydrophobic $\mathrm{C}-\mathrm{H} \mathrm{HB}$ donor cavities. For instance, Sindelar's water-soluble bambus[6] uril ${ }^{22}$ preferentially binds $\mathrm{ClO}_{4}^{-}$over I', while Pittelkow's biotin[6] uril ${ }^{23}$ is selective for SCN-. Likewise, in Gibb's cavitand ${ }^{66} \mathrm{I}^{-}$binding is over an order of magnitude weaker than that of $\mathrm{ReO}_{4}^{-}$and $\mathrm{ClO}_{4}^{-}$. Importantly, this highlights the overriding role of $\sigma$-hole interactions in I- recognition by $\mathbf{1 a}$ and $\mathbf{2}_{\mathrm{Te}}$.

Further evidence of the influence of $\sigma$-holes can be seen in comparison with 1ан, which exhibits a weaker and less selective anion binding ability. Being modestly selective for $\mathrm{I}^{-}$, it displays surprisingly high affinity for the more hydrophilic $\mathrm{Cl}^{-}$. Interestingly, $\mathrm{ReO}_{4}^{-}$was bound strongly only by 
1a and 2 Te and not $\mathbf{1} \mathbf{a}$, possibly implying an intrinsic $\sigma$ hole preference for the oxoanion and better size complementarity with the XB/ChB anion binding site. ${ }^{48,67,68}$

Table 2. Affinities of $1 \mathrm{a}, \mathbf{2}_{\mathrm{Te}}$ and $1 \mathrm{a}_{\mathrm{H}}$ for a range of anions determined in water by ITC.

\begin{tabular}{|c|c|c|c|c|c|c|}
\hline Host & Guest & $\beta_{2}\left[\mathbf{M}^{-2}\right]^{a}$ & $K_{1}\left[M^{-1}\right]$ & $K_{2}\left[\mathbf{M}^{-1}\right]$ & $\Delta H[\mathrm{~kJ} / \mathrm{mol}]$ & $T \Delta S[\mathrm{~kJ} / \mathrm{mol}]$ \\
\hline \multirow{6}{*}{$1 a$} & $\mathrm{NaI}$ & $1.45(0.04) \times 10^{10}$ & $3.16(0.06) \times 10^{4}$ & $4.59(0.16) \times 10^{5}$ & $-52.2(1.0)$ & $5.9(1.0)$ \\
\hline & $\mathrm{NaBr}$ & $3.43(0.50) \times 10^{6}$ & $1.03(0.13) \times 10^{3}$ & $3.34(0.45) \times 10^{3}$ & $-25.6(1.1)$ & $11.7(1.4)$ \\
\hline & $\mathrm{NaCl}$ & $\mathrm{wb}$ & $\mathrm{wb}$ & $\mathrm{wb}$ & $\mathrm{wb}$ & $\mathrm{wb}$ \\
\hline & $\mathrm{NaReO}_{4}$ & $6.66(0.67) \times 10^{8}$ & $4.91(0.22) \times 10^{4}$ & $1.35(0.08) \times 10^{4}$ & $-20.3(0.5)$ & $30.1(0.3)$ \\
\hline & NaSCN & $3.40(0.17) \times 10^{7}$ & $5.38(0.22) \times 10^{3}$ & $6.33(0.55) \times 10^{3}$ & $-31.0(0.9)$ & $12.1(0.8)$ \\
\hline & $\mathrm{NaClO}_{4}$ & $1.21(0.14) \times 10^{5}$ & $5.55(0.74) \times 10^{1}$ & $2.19(0.09) \times 10^{3}$ & $-29.4(3.2)$ & $-0.4(3.4)$ \\
\hline \multirow{6}{*}{$2_{\mathrm{Te}}$} & $\mathrm{NaI}$ & $2.64(0.05) \times 10^{7}$ & $3.67(0.41) \times 10^{2}$ & $7.30(1.00) \times 10^{4}$ & $-31.6(2.3)$ & $10.1(2.2)$ \\
\hline & $\mathrm{NaBr}$ & $1.26(0.70) \times 10^{3}$ & $1.69(0.55) \times 10^{2}$ & $6.94(1.56) \times 10^{0}$ & $-13.9(6.0)$ & $3.2(6.8)$ \\
\hline & $\mathrm{NaCl}$ & $\mathrm{wb}$ & $\mathrm{wb}$ & $\mathrm{wb}$ & $\mathrm{wb}$ & $\mathrm{wb}$ \\
\hline & $\mathrm{NaReO}_{4}$ & $1.58(0.11) \times 10^{6}$ & $1.84(0.18) \times 10^{2}$ & $8.67(1.09) \times 10^{3}$ & $-25.4(2.5)$ & $9.4(2.5)$ \\
\hline & NaSCN & $5.70(0.25) \times 10^{6}$ & $4.92(0.12) \times 10^{2}$ & $1.16(0.05) \times 10^{4}$ & $-2.0(0.5)$ & $35.9(0.5)$ \\
\hline & $\mathrm{NaClO}_{4}$ & $\mathrm{wb}$ & $\mathrm{wb}$ & $\mathrm{wb}$ & $\mathrm{wb}$ & $\mathrm{wb}$ \\
\hline \multirow{6}{*}{$1 \mathbf{a}_{\mathbf{H}}$} & $\mathrm{NaI}$ & & $3876(21)$ & & $-23.2(0.1)$ & $-2.7(0.1)$ \\
\hline & $\mathrm{NaBr}$ & & $---b$ & & $---b$ & $---b$ \\
\hline & $\mathrm{NaCl}$ & & 3367 (983) & & $-0.5(0.1)$ & $19.7(0.7)$ \\
\hline & $\mathrm{NaReO}_{4}$ & & $\mathrm{wb}$ & & $\mathrm{wb}$ & $\mathrm{wb}$ \\
\hline & NaSCN & & 346 (14) & & $-21.7(0.5)$ & $-7.2(0.6)$ \\
\hline & $\mathrm{NaClO}_{4}$ & & $2000(14)$ & & $-23.3(0.1)$ & $-4.5(0.1)$ \\
\hline
\end{tabular}

$\mathrm{wb}$ - weak binding (too weak to quantify). Uncertainties are given in parentheses. All experiments were done in unbuffered water at $298 \mathrm{~K}$ for $\mathbf{1 a}$ and $\mathbf{1} \mathbf{a}_{\mathbf{H}}$ or at $293 \mathrm{~K}$ for $\mathbf{2}_{\mathrm{Te}}$. Formation constants of 2:1 host-guest complex. bNo satisfactory 1:1 fit obtained, possible complex binding equilibria.

All ITC experiments presented in Table 1 and Table 2 were done in unbuffered water, as all anions of interest are $\mathrm{pH}$ independent at $\mathrm{pH}>3$. Likewise, the receptors do not contain significantly acidic or basic functions; in particular, the basicity of 1,2,3-triazoles is known to be very weak. ${ }^{69}$ Additional titrations done in buffered solutions (Table S3-2) revealed almost unchanged $\mathrm{I}^{-}$binding by $\mathbf{1 c}$ at $\mathrm{pH} 4$ (citrate buffer, $\beta_{2}=2.22(0.33) \times 10^{11}$ ) and $\mathrm{pH} 7.5$ (HEPES buffer, $\left.\beta_{2}=2.88(0.87) \times 10^{11}\right)$. Small increases in affinity can be attributed to ionic strength rather than $\mathrm{pH}$ effects. In $\mathrm{pH} 10$ $\mathrm{NaHCO}_{3} / \mathrm{Na}_{2} \mathrm{CO}_{3}$ buffer the binding was slightly weakened $\left(\beta_{2}=3.65(0.12) \times 10^{10}\right)$ which indicates possible competition from $\mathrm{HCO}_{3}^{-}$or $\mathrm{OH}^{-}$ions. Additionally, no cation influence was observed in an experiment using CsI rather than NaI $\left(\beta_{2}=1.49(0.25) \times 10^{11}\right)$. This confirms the expected lack of alkali metal binding sites in the receptor structure.

\section{Computational studies}

Further structural insights into the 2:1 host-iodide stoichiometric complexes of $\mathbf{1 a}$ and $\mathbf{2}_{\mathrm{Te}}$ in water were obtained by molecular dynamics (MD) simulations, carried out using the AMBER software package ${ }^{70}$ and the General AMBER Force Field (GAFF). ${ }^{71,72}$ In addition, for the $\mathbf{2}_{\text {Te }}$ receptor, force field bonding parameters were developed for the tellurium centre. The multiple $\mathrm{XB}$ and $\mathrm{ChB}$ interactions were described by resorting to extra points of charge fol- lowing the modelling approach reported in our previous works. ${ }^{46,47,49,73-77}$ The modelling details are thoroughly described in Section S7 of the ESI.

The starting binding arrangements of 2:1 host-guest complexes of $1 \mathbf{a}$ and 2 Te were generated as follows: two receptor molecules were superimposed with the formation of a binding pocket, in which one iodide was inserted almost equidistant from the eight convergent binding units. In addition, initial binding arrangements $A, B$, and $C$, differing in the relative spatial disposition of the central phenylene rings of the two individual receptors ( $\alpha$ phenyl rings) were considered, as depicted in Figure 4. These three ideal binding arrangements are characterised by the $\omega$ torsion angle, between the centroids of the $\alpha$ phenyl rings and the axis defined by the centroids of the four triazole rings of each receptor. In $A$ and $B$ the $\alpha$ phenyl rings of the two monomers are face-to-face and opposite to each other, leading to $\omega$ torsion angles of 0 and $180^{\circ}$, respectively, while the intermediate arrangement $C$ has an $\omega$ angle of $90^{\circ}$. Afterwards, the $A, B$ and $C$ binding arrangements of $1 \mathbf{a}$ and $2_{\mathrm{Te}}$ structures were subject to preliminary conformational analyses at high temperature by MD simulations in the gas phase, as detailed in ESI. For both host-guest systems, three Molecular Mechanics (MM) energy minimised structures were selected and are shown in Figure 4 for $\mathbf{1 a}$ and in Figure S7-1 for $\mathbf{2}_{\text {Te. }}$. 

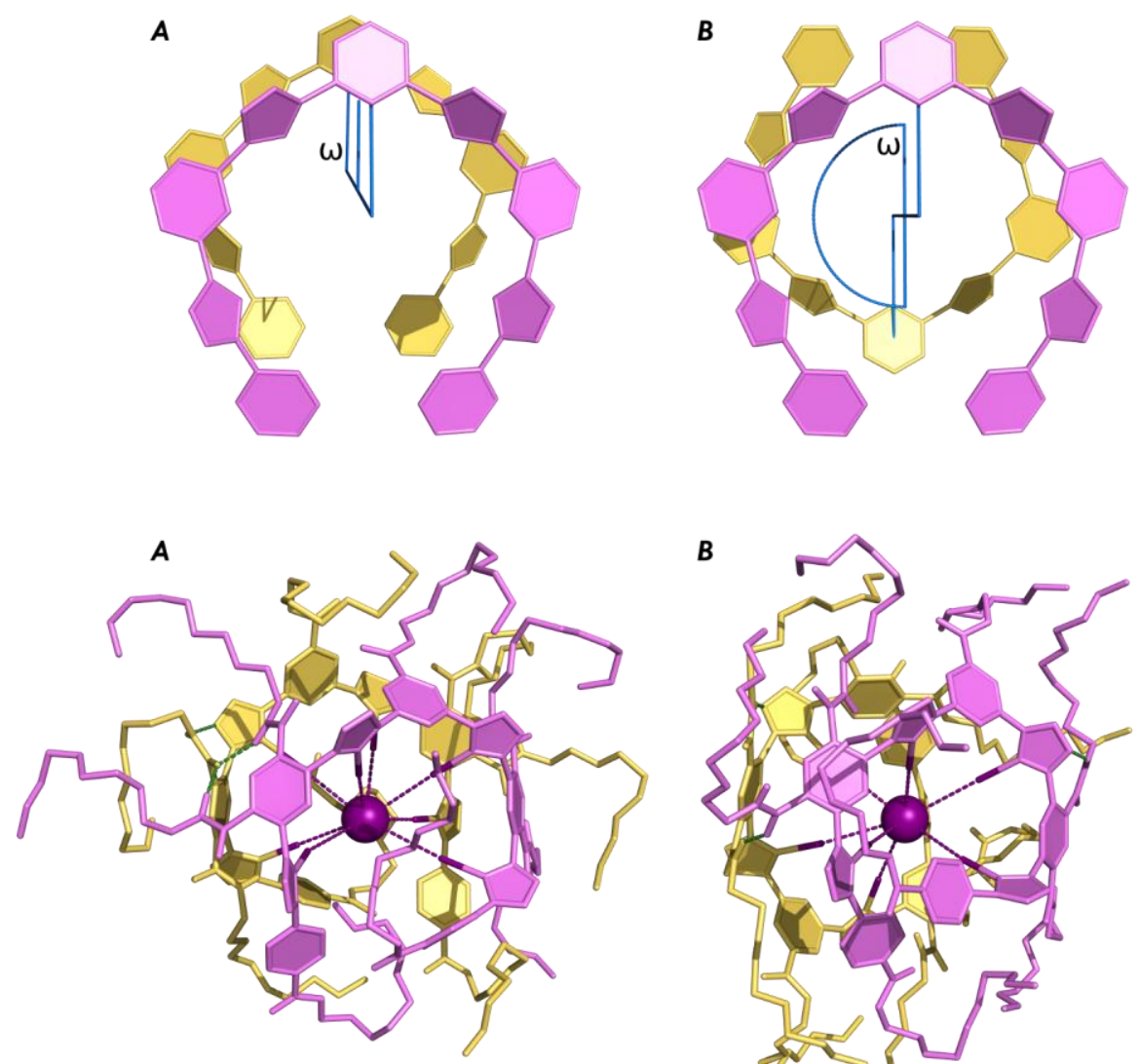

B

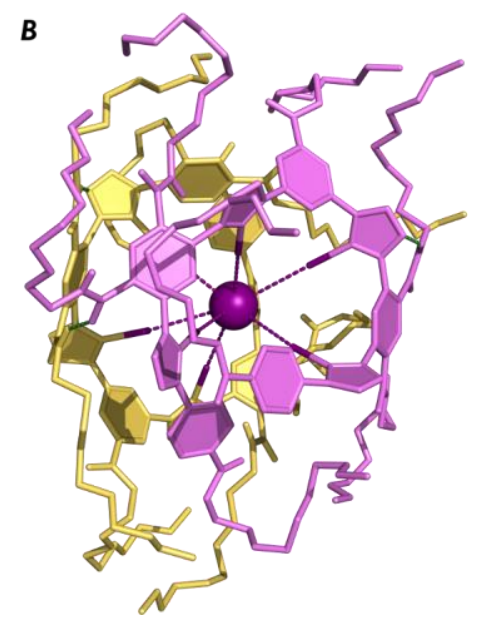

C
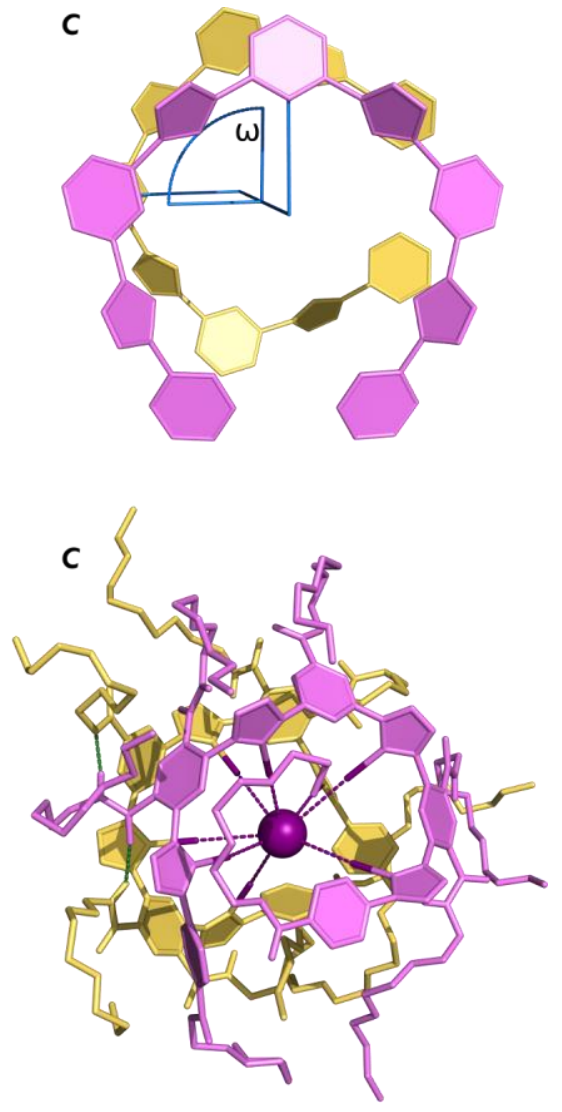

Figure 4. Top: Sketches of binding arrangements $A, B$ and $C$ in 2:1 host-guest complexes showing $\omega$ torsion angle, defined by the centroids of the $\alpha$ rings and of the four triazole binding units of each foldamer. Bottom: MM structures of the 2:1 complexes (1a) $2 \cdot \mathbf{I}^{-}$ in binding arrangements $A, B$ and $C$. The XB and HB interactions are shown in purple and green dashed lines, respectively.

Table 3. Average number and dimensions of XB or ChB interactions for 2:1 host-guest complexes of 1a and $2 \mathrm{Te}$ in binding arrangements $A, B, C{ }^{a}$

\begin{tabular}{ccccc}
\hline Host & Binding arrangement & № of XB/ChB bonds ${ }^{b}$ & $\mathrm{I} / \mathrm{Te} \cdots \mathrm{I}^{-}$distance $(\AA)^{b}$ & $\angle \mathrm{C}_{\text {trz }}-\mathrm{I} / \mathrm{Te}^{b} \cdots \mathrm{I}^{-}\left({ }^{\circ}\right)^{b}$ \\
\hline \multirow{4}{*}{$\mathbf{1 a}$} & $\mathrm{A}$ & $6.6 \pm 0.6$ & $4.03 \pm 0.15$ & $171.2 \pm 5.9$ \\
& $\mathrm{~B}$ & $6.0 \pm 0.2$ & $3.95 \pm 0.21$ & $172.6 \pm 4.1$ \\
& $\mathrm{C}$ & $6.8 \pm 0.4$ & $4.02 \pm 0.19$ & $173.1 \pm 3.6$ \\
& $A+B+C$ & $6.5 \pm 0.6$ & $4.00 \pm 0.19$ & $172.3 \pm 4.7$ \\
\hline \multirow{2}{*}{$\mathbf{T e}_{\mathrm{Te}}$} & $\mathrm{A}$ & $5.1 \pm 0.6$ & $4.07 \pm 0.15$ & $165.5 \pm 5.6$ \\
& $\mathrm{~B}$ & $5.4 \pm 0.6$ & $4.10 \pm 0.17$ & $163.7 \pm 4.5$ \\
& $\mathrm{C}$ & $4.7 \pm 0.5$ & $4.14 \pm 0.17$ & $163.9 \pm 4.2$ \\
\hline
\end{tabular}

$a$ Values estimated from MD simulations in water in binding arrangements $A, B, C(N=600000)$ or their concatenated data $(A+B$ $+C ; N=1800000) ;{ }^{b} \mathrm{XB}$ and $\mathrm{ChB}$ interactions were accounted using distances shorter than $4.5 \AA$ and angles wider than $150^{\circ}$.

The values for the $\omega$ angle in the gas-phase MM minimised structures of $1 \mathrm{a}$ are $20.6^{\circ}(A), 172.2^{\circ}(B)$, and $69.6^{\circ}(C)$, while in $2_{\mathrm{Te}}$ this angle is $44.8^{\circ}(A), 146.1^{\circ}(B)$ and $95.4^{\circ}(C)$. Moreover, the seven peripheral PEG-side chains of each monomer are folded around the capsule core and are consequently hampering the eventual access of water molecules to the binding pocket. Thus, iodide recognition was also investigated stretching the PEG-side chains of $\mathbf{1 a}$ and $\mathbf{2}_{\mathrm{Te}}$ in the three starting arrangements. Ultimately, two alternative scenarios for the $A, B$, and $C$ spatial dispositions, with folded and unfolded PEG-side chains, were af- forded and appointed for subsequent MD simulations carried out under periodic boundary conditions in cubic boxes with 11500 TIP3P water molecules. The foldamer capsules $1 \mathrm{a}$ and 2 Te were simulated along three independent runs of $100 \mathrm{~ns}$ each, leading to a total of $(3 \times 2 \times 3 \times 100=)$ $1.8 \mu \mathrm{s}$ of MD simulation for each host. Notably, along the equilibration period the unfolded PEG-side chains have refolded, adopting equivalent dispositions to the ones observed in the gas-phase. Consequently, the sampling data of six independent MD runs for the $A, B$ and $C$ binding arrangements of $\mathbf{1 a}$ and $\mathbf{2}_{\mathrm{Te}}$ are treated together. 

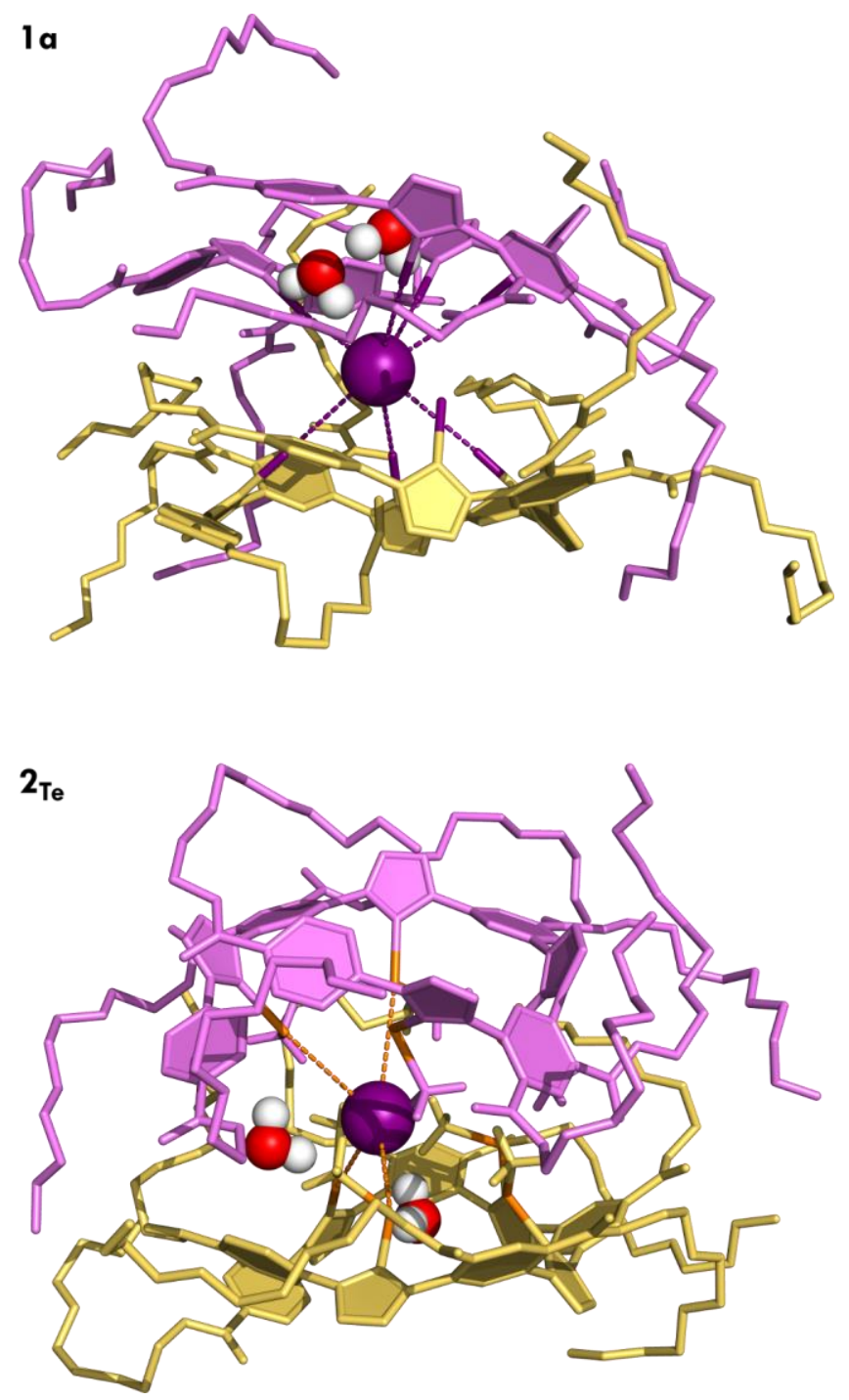

Figure 5. Representative MD snapshots of dimeric capsules of 1a and $2_{\mathrm{Te}}$, in binding arrangement $\mathrm{A}$, with the iodide guest establishing XB (purple dashed lines) or ChB (orange dashed lines) interactions with the binding units of the two foldamer entities, while being surrounded by a few water molecules.

Noteworthy, the dimeric capsules of $\mathbf{1 a}$ and $\mathbf{2}_{\mathrm{Te}}$ are maintained throughout the simulation time, with the iodide guest kept inside of the binding pocket, as illustrated in Figure 5 for binding arrangement $A$ of both complexes. Equivalent depictions are presented in Figures S7-2 and S7-3 for the $B$ and $C$ scenarios of these dimeric receptor iodide complexes. The numbers and average dimensions of the $\mathrm{XB}$ and $\mathrm{ChB}$ interactions are summarised in Table 3. Receptor $1 \mathrm{a}$ binds $\mathrm{I}^{-}$with $c a .7$ intermittent XB interactions for arrangements $A$ and $C$ or 6 for arrangement $B$. These results indicate that at least six of the eight putative $\mathrm{XB}$ binding units recognize the iodide during the course of simulation time. The dimensions of the XB interactions are indistinguishable between binding arrangements, with $\mathrm{C}_{\text {trz }}-\mathrm{I} \cdots \mathrm{I}^{-}$(trz $=$triazole) angles roughly linear and $\mathrm{I}^{\prime} \cdot \mathrm{I}^{-}$distances of $c a$. $4.0 \AA$, showing that the iodide guest is tightly bonded to the capsule. In addition, up to $14 \mathrm{~N}-\mathrm{H} \cdots \mathrm{O}$ and $\mathrm{N}$ $\mathrm{H} \cdots \mathrm{N}_{\text {trz }}$ hydrogen bonds between receptor molecules were intermittently observed, also assisting the maintenance of the capsular architecture (see Table S7-1). In agreement with these synergetic non-covalent interactions, the three binding arrangements preserve the initial orientations, as indicated by the average $\omega$ torsion angles of $19.2 \pm 9.1^{\circ}$, $175.0 \pm 5.4^{\circ}$, and $73.3 \pm 7.2^{\circ}$ for $A, B$ and $C$, respectively.

Concerning iodide binding by $\mathbf{2}_{\mathrm{Te}}$ capsule, the anion is shared by the eight MeTe binding units, with an average of ca. $5 \mathrm{ChB}$ interactions, regardless of the binding scenario. Moreover, in spite of the similarity between the average Te $\cdots \mathrm{I}^{-}$and $\mathrm{I}^{-} \cdot \mathrm{I}^{-}$distances (see Table 3 ), the $\mathrm{C}_{\mathrm{trz}}-\mathrm{Te} \cdots \mathrm{I}^{-}$angles are less linear than the $\mathrm{C}_{\text {trz }}-\mathrm{I} \cdots \mathrm{I}^{-}$ones. In addition, the weaker $\mathrm{ChB}$ interactions are more often interrupted than their sister XB ones within the 1a capsule. In spite of that, the initial relative orientations between monomers in the $A, B$ and $C$ binding arrangements are also preserved, with corresponding $\omega$ angles of $43.7 \pm 7.8^{\circ}, 149.5 \pm 5.1^{\circ}$ and $89.9 \pm 4.5^{\circ}$.

The number of water molecules residing in the capsule binding cavity of $\mathbf{1 a}$ or $\mathbf{2}_{\text {Te }}$ was assessed within $5.0 \AA$ from the guest iodide, concatenating the sampling data of the three binding arrangements. This sphere radius was selected as it roughly corresponds to the outer limit of the host binding cavity defined by the iodine or tellurium binding units. An average of 2 water molecules surrounded the encapsulated anion in both 2:1 host-guest complexes, while an MD simulation of free $\mathrm{I}^{-}$shows that it is solvated by approximately 20 water molecules within the same 5.0 $\AA$ cut-off. In line, the radial distribution function of the water molecules around the iodide, presented in Figure S7-4, clearly shows that the dimeric foldamer capsules of $\mathbf{1 a}$ and $\mathbf{2}_{\text {Te }}$ partially shelter the hosted anion from the solvent molecules at least within a $10 \AA$ shell, as suggested by the gas-phase MM structures (Figures 4 and S7-1) and MD snapshots (Figures 5, S7-2 and S7-3). Moreover, along the MD simulations the equatorial and axial holes of the dimeric capsules are intermittently opened/closed by the flexible PEG-side chains, that act as lids, limiting the access of the water molecules to the centre of the binding cavity. This feature is clearly illustrated in Movie S1.

\section{Fluorescent anion sensing}

Compounds 1b-d incorporate fluorophores in their termini, which are engineered to give fluorescent output upon anion binding. Compounds $\mathbf{1 b}$ and $\mathbf{1 c}$ showed little to no response upon titration with $\mathrm{NaI}$ (see ESI section S6). On the other hand, 1d equipped with well-known 4-amino1,8-naphthalene imide fluorophores ${ }^{78-80}$ displayed nearly 2-fold enhancement of emission intensity (Figure 6). A small hypsochromic shift of emission maximum from 564 $\mathrm{nm}$ to $558 \mathrm{~nm}$ was also observed. This significant 'turn-on' emission observed upon $\mathrm{I}^{-}$addition is especially noteworthy, as the 'heavy atom effect' associated with this anion ${ }^{81}$ often results in dramatic fluorescence attenuation ${ }^{82}$ or small changes in intensity. ${ }^{47,83}$ The main reason for the fluorescence enhancement is most likely the restriction of intramolecular motion ${ }^{84}$ upon $\mathrm{I}^{-}$complex formation. Although it is not clear why only $\mathbf{1 d}$ exhibited a response, this may result from increased separation of its fluorophores from the anion binding site, further reducing the quenching influence of iodide guest. 


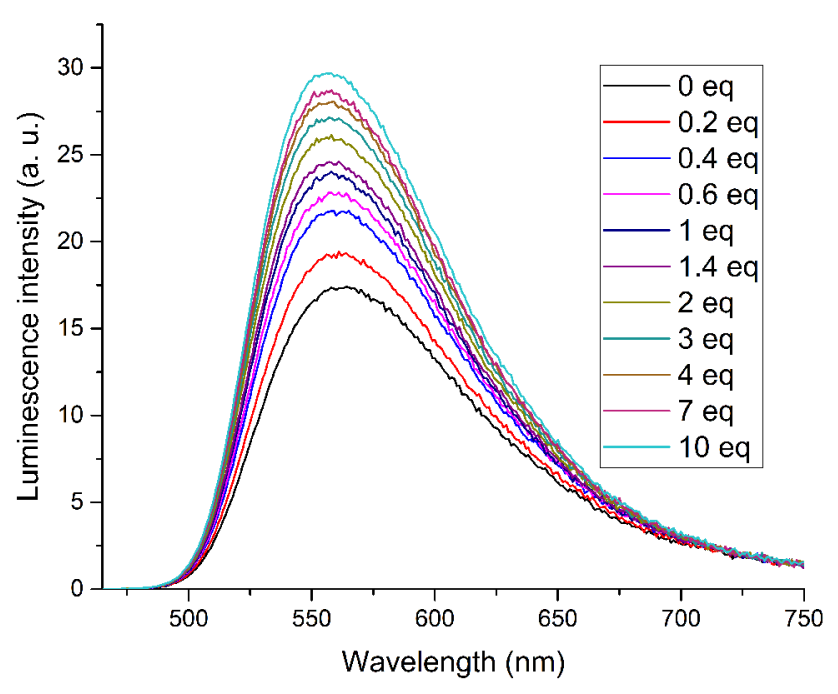

Figure 6. Luminescence spectra of $\mathbf{1 d}\left(100 \mu \mathrm{M}\right.$ in $\mathrm{H}_{2} \mathrm{O}, \lambda_{\mathrm{ex}}=$ $442 \mathrm{~nm}$ ) titrated with $0-10$ equivalents of NaI.

\section{CONCLUSIONS}

In summary, we have achieved exceptionally strong and highly selective $\mathrm{I}^{-}$binding in pure water using unprecedented charge-neutral, non-macrocyclic XB and ChB anion receptors. Anion binding studies in combination with molecular dynamics simulations demonstrate the formation of 2:1 receptor-I- complexes where the $\mathrm{I}^{-}$guest is held by multiple convergent $\sigma$-hole interactions. The hydrophobic nature of $\sigma$-hole donor atoms facilitates this folding and dimeric aggregation of receptor molecules, concomitant with expulsion of water from the anion's hydration shell. This self-assembly of multidentate anion binding sites stabilized by hydrophobic collapse results in extremely high $\mathrm{I}^{-}$ affinity, exceeding that of the natural NIS $\mathrm{I}^{-}$receptor by several orders of magnitude. Additionally, the use of $\sigma$-hole interactions leads to the unique selectivity for I- over other less hydrated anions (e.g. $\mathrm{ClO}_{4}^{-}, \mathrm{SCN}^{-}$), which is in contrast with macrocyclic receptors containing deep hydrophobic cavities.

Binding of $\mathrm{I}^{-}$was predominantly enthalpy-driven in all XB and $\mathrm{ChB}$ receptors, highlighting the formation of the respective $\sigma$-hole interactions. In the first example of a $\mathrm{ChB}$ anion receptor studied in water, close similarity in the properties of $\mathrm{ChB}$ and $\mathrm{XB}$ was found as can be inferred from comparable $K_{1}$ and $\Delta H$ values in $\mathbf{2}_{\mathrm{Te}}$ and $\mathbf{2}_{\mathrm{I}}$ (Table 1 ). In comparison with the $\mathrm{HB}$ analogue $1 \mathbf{a}_{\mathbf{H}}, \mathrm{XB}$ and $\mathrm{ChB}$ receptors displayed overwhelmingly higher $\mathrm{I}^{-}$affinity and selectivity. Additionally, the introduction of fluorescent terminal groups into the XB foldamer receptor design allowed $\mathrm{I}^{-}$sensing capability to be demonstrated based on emission enhancement upon binding. Hence the observations herein further champion and advance halogen and chalcogen bonding as highly effective new tools for the selective binding and sensing of anions in water. Importantly, the strategy of utilising the hydrophobic character of $\sigma$-hole donor atoms for self-assembly of anion binding cavities marks a paradigm shift in exploiting these interactions for anion receptor design.

\section{ASSOCIATED CONTENT}

Synthetic procedures and characterization data for compounds, details of ITC and NMR anion binding studies, computational methods. This material is available free of charge via the Internet at http://pubs.acs.org.

\section{AUTHOR INFORMATION}

\section{Corresponding Author}

*paul.beer@chem.ox.ac.uk

\section{ORCID}

Arseni Borissov: 0000-0002-5408-1534

Igor Marques: 0000-0003-4971-9932

Jason Y. C. Lim: 0000-0002-8020-1720

Vítor Félix: 0000-0001-9380-0418

Martin D. Smith: 0000-0002-8849-488X

Paul D. Beer: 0000-0003-0810-9716

\section{Present Addresses}

J. Y. C. Lim: Institute of Materials Engineering and Research (IMRE), 2 Fusionopolis Way, Singapore 138634.

\section{Author Contributions}

All authors have given approval to the final version of the manuscript.

Notes

The authors declare no competing financial interest.

\section{ACKNOWLEDGMENT}

A. B. is grateful to the EPSRC Centre for Doctoral Training in Synthesis for Biology and Medicine (EP/L015838/1) for a studentship, generously supported by AstraZeneca, Diamond Light Source, Defence Science and Technology Laboratory, Evotec, GlaxoSmithKline, Janssen, Novartis, Pfizer, Syngenta, Takeda, UCB and Vertex.

J. Y. C. L. thanks the Agency for Science, Technology and Research (A*STAR), Singapore, for postgraduate funding.

V. F. acknowledges support from project PTDC/QEQSUP/4283/2014 (POCI-01-0145-FEDER-016895) and CICECO - Aveiro Institute of Materials (UID/CTM/50011/2013), financed by National Funds through the FCT/MEC and cofinanced by QREN-FEDER through COMPETE under the PT2020 Partnership Agreement.

I. M. is grateful for a post-doc grant under project pAGE (Centro-01-0145-FEDER-000003).

\section{ABBREVIATIONS}

$\mathrm{ChB}$, chalcogen bonding; $\mathrm{HB}$, hydrogen bonding; ITC, isothermal titration calorimetry; MD, molecular dynamics; MM, molecular mechanics; XB, halogen bonding.

\section{REFERENCES}

(1) Gale, P. A.; Howe, E. N. W.; Wu, X. Anion Receptor Chemistry. Chem 2016, 1 (3), 351-422.

(2) Schmidtchen, F. P. Inclusion of Anions in Macrotricyclic Quaternary Ammonium Salts. Angew. Chem. Int. Ed. 1977, 16 (10), 720-721.

(3) Lehn, J.-M. Cryptates: Inclusion Complexes of Macropolycyclic Receptor Molecules. Pure Appl. Chem. 1978, 50 (9-10), 871-892.

(4) Dietrich, B.; Fyles, D. L.; Fyles, T. M.; Lehn, J.-M. Anion Coordination Chemistry: Polyguanidinium Salts as Anion Complexones. Helv. Chim. Acta 1979, 62 (8), 2763-2787. 
Macrocyclic and Macrobicyclic Effects on Anion Binding by Polyammonium Receptor Molecules. Helv. Chim. Acta 1988 , 71 (4), 749-756.

(6) Alfonso, I.; Dietrich, B.; Rebolledo, F.; Gotor, V.; Lehn, J.-M. Optically Active Hexaazamacrocycles: Protonation Behavior and Chiral-Anion Recognition. Helv. Chim. Acta 2001, 84 (2), 280-295.

(7) Schmidtchen, F. P.; Berger, M. Artificial Organic Host Molecules for Anions. Chem. Rev. 1997, 97 (5), 1609-1646.

(8) Schmidtchen, F. P. Hosting Anions. the Energetic Perspective. Chem. Soc. Rev. 2010, 39 (10), 3916-3935.

(9) Hirai, M.; Gabbaï, F. P. Squeezing Fluoride out of Water with a Neutral Bidentate Antimony(V) Lewis Acid. Angew. Chem. Int. Ed. 2015, 54 (4), 1205-1209.

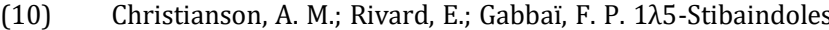
as Lewis Acidic, $\pi$-Conjugated, Fluoride Anion Responsive Platforms. Organometallics 2017, 36 (14), 2670-2676.

(11) Busschaert, N.; Caltagirone, C.; Van Rossom, W.; Gale, P. A. Applications of Supramolecular Anion Recognition. Chem. Rev. 2015, 115 (15), 8038-8155.

(12) Ojida, A.; Mito-Oka, Y.; Inoue, M. A.; Hamachi, I. First Artificial Receptors and Chemosensors toward Phosphorylated Peptide in Aqueous Solution. J. Am. Chem. Soc. 2002, 124 (22), 6256-6258.

(13) Ojida, A.; Mito-Oka, Y.; Sada, K.; Hamachi, I. Molecular Recognition and Fluorescence Sensing of Monophosphorylated Peptides in Aqueous Solution by Bis(Zinc(II)-Dipicolylamine)-Based Artificial Receptors. J Am. Chem. Soc. 2004, 126 (8), 2454-2463.

(14) Melaimi, M.; Gabbaï, F. P. A Heteronuclear Bidentate Lewis Acid as a Phosphorescent Fluoride Sensor. J. Am. Chem. Soc. 2005, 127 (27), 9680-9681.

(15) Smith, D. G.; Law, G. L.; Murray, B. S.; Pal, R.; Parker, D. Wong, K. L. Evidence for the Optical Signalling of Changes in Bicarbonate Concentration within the Mitochondrial Region of Living Cells. Chem. Commun. 2011, 47 (26), 7347-7349.

(16) Liu, T.; Nonat, A.; Beyler, M.; Regueiro-Figueroa, M. Nchiminono, K.; Jeannin, O.; Camerel, F.; Debaene, F.; Cianférani-Sanglier, S.; Tripier, R.; Platas-Iglesias, C.; Charbonnière, L. J. Supramolecular Luminescent Lanthanide Dimers for Fluoride Sequestering and Sensing. Angew. Chem. Int. Ed. 2014, 53 (28), 7259-7263.

(17) Mailhot, R.; Traviss-Pollard, T.; Pal, R.; Butler, S. J. Cationic Europium Complexes for Visualizing Fluctuations in Mitochondrial ATP Levels in Living Cells. Chem. Eur. J. 2018, 24 (42), 10745-10755.

(18) Gale, P. A. Anion Receptor Chemistry. Chem. Commun 2011 47, 82-86.

(19) Kubik, S.; Kirchner, R.; Nolting, D.; Seidel, J. A Molecular Oyster: A Neutral Anion Receptor Containing Two Cyclopeptide Subunits with a Remarkable Sulfate Affinity in Aqueous Solution. J. Am. Chem. Soc. 2002, 124 (43), 1275212760.

(20) Schaly, A.; Belda, R.; García-España, E.; Kubik, S. Selective Recognition of Sulfate Anions by a Cyclopeptide-Derived Receptor in Aqueous Phosphate Buffer. Org. Lett. 2013, 15 (24), 6238-6241.

(21) Havel, V.; Svec, J.; Wimmerova, M.; Dusek, M.; Pojarova, M.; Sindelar, V. Bambus[n]Urils: A New Family of Macrocyclic Anion Receptors. Org. Lett. 2011, 13 (15), 4000-4003.

(22) Yawer, M. A.; Havel, V.; Sindelar, V. A Bambusuril Macrocycle That Binds Anions in Water with High Affinity and Selectivity. Angew. Chem. Int. Ed. 2015, 54 (1), 276-279.

(23) Lisbjerg, M.; Nielsen, B. E.; Milhøj, B. O.; Sauer, S. P. A.; Pittelkow, M. Anion Binding by Biotin[6]Uril in Water. Org. Biomol. Chem. 2015, 13 (2), 369-373.

(24) Lisbjerg, M.; Valkenier, H.; Jessen, B. M.; Al-Kerdi, H.; Davis, A P.; Pittelkow, M. Biotin[6]Uril Esters: Chloride-Selective Transmembrane Anion Carriers Employing C-H $\cdots$ anion Interactions. J. Am. Chem. Soc. 2015, 137 (15), 4948-4951.

(25) Suk, J.; Chae, M. K.; Jeong, K.-S. Indolocarbazole-Based Anion Receptors and Molecular Switches. Pure Appl. Chem. 2012 84 (4), 953-964.

(26) Politzer, P.; Murray, J. S.; Clark, T. Halogen Bonding and
Other $\sigma$-Hole Interactions: A Perspective. Phys. Chem. Chem. Phys. 2013, 15 (27), 11178.

(27) Cavallo, G.; Metrangolo, P.; Milani, R.; Pilati, T.; Priimagi, A.; Resnati, G.; Terraneo, G. The Halogen Bond. Chem. Rev. 2016 116 (4), 2478-2601.

(28) Lim, J. Y. C.; Beer, P. D. Sigma-Hole Interactions in Anion Recognition. Chem 2018, 4 (4), 731-783.

(29) Robertson, C. C.; Perutz, R. N.; Brammer, L.; Hunter, C. A. A Solvent-Resistant Halogen Bond. Chem. Sci. 2014, 5 (11) 4179-4183.

(30) Pascoe, D. J.; Ling, K. B.; Cockroft, S. L. The Origin of Chalcogen-Bonding Interactions. J. Am. Chem. Soc. 2017, 139 (42), 15160-15167.

(31) Tepper, R.; Schubert, U. S. Halogen Bonding in Solution: Anion Recognition, Templated Self-Assembly, and Organocatalysis. Angew. Chem. Int. Ed. 2018, 57 (21), 60046016

(32) Amendola, V.; Bergamaschi, G.; Boiocchi, M.; Fusco, N.; La Rocca, M. V.; Linati, L.; Lo Presti, E.; Mella, M.; Metrangolo, P. Miljkovic, A. Novel Hydrogen- and Halogen-Bonding Anion Receptors Based on 3-Iodopyridinium Units. RSC Adv. 2016, 6 (72), 67540-67549.

(33) Mungalpara, D.; Stegmüller, S.; Kubik, S. A Neutral Halogen Bonding Macrocyclic Anion Receptor Based on a Pseudocyclopeptide with Three 5-Iodo-1,2,3-Triazole Subunits. Chem. Commun. 2017, 53 (37), 5095-5098.

(34) Jungbauer, S. H.; Schindler, S.; Herdtweck, E.; Keller, S.; Huber, S. M. Multiple Multidentate Halogen Bonding in Solution, in the Solid State, and in the (Calculated) Gas Phase. Chem. Eur. J. 2015, 21 (39), 13625-13636.

(35) Jungbauer, S. H.; Huber, S. M. Cationic Multidentate HalogenBond Donors in Halide Abstraction Organocatalysis: Catalyst Optimization by Preorganization. J. Am. Chem. Soc. 2015, 137 (37), 12110-12120

(36) Cao, J.; Yan, X.; He, W.; Li, X.; Li, Z.; Mo, Y.; Liu, M.; Jiang, Y. B. C-I $\cdots \pi$ Halogen Bonding Driven Supramolecular Helix of Bilateral N-Amidothioureas Bearing $\beta$-Turns. J. Am. Chem. Soc. 2017, 139 (19), 6605-6610.

(37) Dumele, O.; Schreib, B.; Warzok, U.; Trapp, N.; Schalley, C. A.; Diederich, F. Halogen-Bonded Supramolecular Capsules in the Solid State, in Solution, and in the Gas Phase. Angew. Chem. Int. Ed. 2017, 56 (4), 1152-1157.

(38) Szell, P. M. J.; Siiskonen, A.; Catalano, L.; Cavallo, G.; Terraneo, G.; Priimagi, A.; Bryce, D. L.; Metrangolo, P. Halogen-Bond Driven Self-Assembly of Triangular Macrocycles. New J. Chem. 2018, 42 (13), 10467-10471.

(39) Zapata, F.; González, L.; Caballero, A.; Bastida, A.; Bautista, D.; Molina, P. Interlocked Supramolecular Polymers Created by Combination of Halogen- and Hydrogen-Bonding Interactions through Anion-Template Self-Assembly. J. Am. Chem. Soc. 2018, 140 (6), 2041-2045.

(40) Benz, S.; Macchione, M.; Verolet, Q.; Mareda, J.; Sakai, N.; Matile, S. Anion Transport with Chalcogen Bonds. J. Am. Chem. Soc. 2016, 138 (29), 9093-9096.

(41) Jentzsch, A. V.; Matile, S. Transmembrane Halogen-Bonding Cascades. J. Am. Chem. Soc. 2013, 135 (14), 5302-5303.

(42) Macchione, M.; Tsemperouli, M.; Goujon, A.; Mallia, A. R.; Sakai, N.; Sugihara, K.; Matile, S. Mechanosensitive Oligodithienothiophenes: Transmembrane Anion Transport Along Chalcogen-Bonding Cascades. Helv. Chim. Acta 2018 101 (4), e1800014.

(43) Jentzsch, A. V.; Emery, D.; Mareda, J.; Nayak, S. K. Metrangolo, P.; Resnati, G.; Sakai, N.; Matile, S. Transmembrane Anion Transport Mediated by HalogenBond Donors. Nat. Commun. 2012, 3, Article number: 905.

(44) Massena, C. J.; Wageling, N. B.; Decato, D. A.; Martin Rodriguez, E.; Rose, A. M.; Berryman, O. B. A Halogen-BondInduced Triple Helicate Encapsulates Iodide. Angew. Chem. Int. Ed. 2016, 55 (40), 12398-12402.

(45) Massena, C. J.; Decato, D. A.; Berryman, O. B. A Long-Lived Halogen-Bonding Anion Triple Helicate Accommodates Rapid Guest Exchange. Angew. Chem. Int. Ed. 2018, 57 (49), 16109-16113.

(46) Langton, M. J.; Robinson, S. W.; Marques, I.; Félix, V.; Beer, P. 
D. Halogen Bonding in Water Results in Enhanced Anion Recognition in Acyclic and Rotaxane Hosts. Nat. Chem. 2014, 6 (12), 1039-1043.

(47) Langton, M. J.; Marques, I.; Robinson, S. W.; Félix, V.; Beer, P. D. Iodide Recognition and Sensing in Water by a HalogenBonding Ruthenium(II)-Based Rotaxane. Chem. Eur. J. 2016 , 22 (1), 185-192.

(48) Lim, J. Y. C.; Beer, P. D. Superior Perrhenate Anion Recognition in Water by a Halogen Bonding Acyclic Receptor. Chem. Commun. 2015, 51 (17), 3686-3688.

(49) Lim, J. Y. C.; Marques, I.; Thompson, A. L.; Christensen, K. E.; Félix, V.; Beer, P. D. Chalcogen Bonding Macrocycles and [2]Rotaxanes for Anion Recognition. J. Am. Chem. Soc. 2017, 139 (8), 3122-3133.

(50) Hua, Y.; Liu, Y.; Chen, C. H.; Flood, A. H. Hydrophobic Collapse of Foldamer Capsules Drives Picomolar-Level Chloride Binding in Aqueous Acetonitrile Solutions. J. Am. Chem. Soc 2013, 135 (38), 14401-14412.

(51) Liu, Y.; Parks, F. C.; Zhao, W.; Flood, A. H. SequenceControlled Stimuli-Responsive Single-Double Helix Conversion between 1:1 and 2:2 Chloride-Foldamer Complexes. J. Am. Chem. Soc. 2018, 140 (45), 15477-15486.

(52) Nicola, J. P.; Carrasco, N.; Amzel, L. M. Physiological Sodium Concentrations Enhance the Iodide Affinity of the $\mathrm{Na}+/ \mathrm{I}-$ Symporter. Nat. Commun. 2014, Article number: 3948.

(53) Borissov, A.; Lim, J. Y. C.; Brown, A.; Christensen, K. E.; Thompson, A. L.; Smith, M. D.; Beer, P. D. Neutral Iodotriazole Foldamers as Tetradentate Halogen Bonding Anion Receptors. Chem. Commun. 2017, 53 (16), 2483-2486.

(54) Hein, J. E.; Tripp, J. C.; Krasnova, L. B.; Sharpless, K. B.; Fokin, V. V. Copper(I)-Catalyzed Cycloaddition of Organic Azides and 1-Iodoalkynes. Angew. Chem. Int. Ed. 2009, 48 (43), 8018-8021.

(55) Yao, T.; Larock, R. C. Regio- and Stereoselective Synthesis of Isoindolin-1-Ones via Electrophilic Cyclization. J. Org. Chem. 2005, 70 (4), 1432-1437.

(56) Bubar, A.; Estey, P.; Lawson, M.; Eisler, S. Synthesis of Extended, $\pi$-Conjugated Isoindolin-1-Ones. J. Org. Chem. 2012, 77 (3), 1572-1578.

(57) Stefani, H. A.; Vasconcelos, S. N. S.; Manarin, F.; Leal, D. M.; Souza, F. B.; Madureira, L. S.; Zukerman-Schpector, J.; Eberlin, M. N.; Godoi, M. N.; De Souza Galaverna, R. Synthesis of 5-Organotellanyl-1H-1,2,3-Triazoles: Functionalization of the 5-Position Scaffold by the Sonogashira Cross-Coupling Reaction. Eur. J. Org. Chem. 2013, No. 18, 3780-3785.

(58) Potapov, V. A.; Amosova, S. V; Khangurov, A. V; Petrov, P. A. SYNTHESIS OF ACETYLENIC TELLURIDES BY THE IODOMETHANE-INDUCED REACTION OF DIALKYL DITELLURIDES WITH PHENYLACETYLENE. Phosphorus, Sulfur, and Silicon 1993, 79, 273-275.

(59) Hey, M. J.; Ilett, S. M.; Davidson, G. Effect of Temperature on Poly(Ethylene Oxide) Chains in Aqueous Solution. A Viscometric, 1H NMR and Raman Spectroscopic Study. J. Chem. Soc. Faraday Trans. 1995, 91 (21), 3897-3900.

(60) Aroua, S.; Tiu, E. G. V.; Ishikawa, T.; Yamakoshi, Y. WellDefined Amphiphilic C60-PEG Conjugates: Water-Soluble and Thermoresponsive Materials. Helv. Chim. Acta 2016, 99 (10), 805-813.

(61) Li, Y.; Flood, A. H. Pure C-H Hydrogen Bonding to Chloride Ions: A Preorganized and Rigid Macrocyclic Receptor Angew. Chem. Int. Ed. 2008, 47 (14), 2649-2652.

(62) Hua, Y.; Ramabhadran, R. O.; Karty, J. a; Raghavachari, K. Flood, A. H. Two Levels of Conformational Pre-Organization Consolidate Strong $\mathrm{CH}$ Hydrogen Bonds in ChlorideTriazolophane Complexes. Chem. Commun. 2011, 47, 59795981.

(63) Juwarker, H.; Lenhardt, J. M.; Pham, D. M.; Craig, S. L. 1,2,3Triazole $\mathrm{CH} \cdot \cdots \mathrm{Cl}-$ Contacts Guide Anion Binding and Concomitant Folding in 1,4-Diaryl Triazole Oligomers. Angew. Chem. Int. Ed. 2008, 47 (20), 3740-3743.

(64) Juwarker, H.; Lenhardt, J. M.; Castillo, J. C.; Zhao, E.; Krishnamurthy, S.; Jamiolkowski, R. M.; Kim, K. H.; Craig, S. L. Anion Binding of Short, Flexible Aryl Triazole Oligomers. J. Org. Chem. 2009, 74 (23), 8924-8934.
Smith, D. W. Ionic Hydration Enthalpies. J. Chem. Educ. 1977, 54 (9), 540 .

(66) Jordan, J. H.; Gibb, C. L. D.; Wishard, A.; Pham, T.; Gibb, B. C. Ion-Hydrocarbon and/or Ion-Ion Interactions: Direct and Reverse Hofmeister Effects in a Synthetic Host. J. Am. Chem. Soc. 2018, 140 (11), 4092-4099.

(67) Massena, C. J.; Riel, A. M. S.; Neuhaus, G. F.; Decato, D. A.; Berryman, O. B. Solution and Solid-Phase Halogen and C-H Hydrogen Bonding to Perrhenate. Chem. Commun. 2015, 51 (8), 1417-1420.

(68) Cornes, S. P.; Sambrook, M. R.; Beer, P. D. Selective Perrhenate Recognition in Pure Water by Halogen Bonding and Hydrogen Bonding Alpha-Cyclodextrin Based Receptors. Chem. Commun. 2017, 53 (27), 3866-3869.

(69) Abboud, J. L. M.; Foces-Foces, C.; Notario, R.; Trifonov, R. E. Volovodenko, A. P.; Ostrovskii, V. A.; Alkorta, I.; Elguero, J. Basicity of $\mathrm{N}-\mathrm{H}$ - and N-Methyl-1,2,3-Triazoles in the Gas Phase, in Solution, and in the Solid State - An Experimental and Theoretical Study. Eur. J. Org. Chem. 2001, No. 16, 30133024.

(70) Case, D. A.; Betz, R. M.; Botello-Smith, W.; Cerutti, D. S. Cheatham, T. E.; Darden, T. A.; Duke, R. E.; Giese, T. J.; Gohlke, H.; Goetz, A. W.; Homeyer, N.; Izadi, S.; Janowski, P.; Kaus, J.; Kovalenko, A.; Lee, T. S. Amber 2016. Univ. California, San Fr. 2016.

(71) Wang, J.; Wolf, R. M.; Caldwell, J. W.; Kollman, P. A.; Case, D. A. Development and Testing of a General Amber Force Field. J. Comput. Chem. 2004, 25 (9), 1157-1174.

(72) Wang, J.; Wolf, R. M.; Caldwell, J. W.; Kollman, P. A.; Case, D. A. Erratum: Development and Testing of a General Amber Force Field (Journal of Computational Chemistry (2004) 25 (1157)). J. Comput. Chem. 2005, 26 (1), 114

(73) Barendt, T. A.; Docker, A.; Marques, I.; Félix, V.; Beer, P. D. Selective Nitrate Recognition by a Halogen-Bonding FourStation [3]Rotaxane Molecular Shuttle. Angew. Chem. Int. Ed. 2016, 55 (37), 11069-11076.

(74) Lim, J. Y. C.; Marques, I.; Ferreira, L.; Félix, V.; Beer, P. D. Enhancing the Enantioselective Recognition and Sensing of Chiral Anions by Halogen Bonding. Chem. Commun. 2016, 52 (32), 5527-5530.

(75) Lim, J. Y. C.; Marques, I.; Félix, V.; Beer, P. D. Enantioselective Anion Recognition by Chiral Halogen-Bonding [2]Rotaxanes. J. Am. Chem. Soc. 2017, 139 (35), 12228-12239.

(76) Lim, J. Y. C.; Marques, I.; Félix, V.; Beer, P. D. A Chiral Halogen-Bonding [3]Rotaxane for the Recognition and Sensing of Biologically Relevant Dicarboxylate Anions. Angew. Chem. Int. Ed. 2018, 57 (2), 584-588.

(77) Lim, J. Y. C.; Marques, I.; Félix, V.; Beer, P. D. Chiral Halogen and Chalcogen Bonding Receptors for Discrimination of Stereo- and Geometric Dicarboxylate Isomers in Aqueous Media. Chem. Commun. 2018, 54 (77), 10851-10854.

(78) Fu, Y.; Zhang, J.; Wang, H.; Chen, J. L.; Zhao, P.; Chen, G. R.; He, $\mathrm{X}$. P. Intracellular $\mathrm{PH}$ Sensing and Targeted Imaging of Lysosome by a Galactosyl Naphthalimide-Piperazine Probe. Dye. Pigment. 2016, 133, 372-379.

(79) Loving, G.; Imperiali, B. A Versatile Amino Acid Analogue of the Solvatochromic Fluorophore 4-N,N-Dimethylamino-1,8Naphthalimide: A Powerful Tool for the Study of Dynamic Protein Interactions. J. Am. Chem. Soc. 2008, 130 (41), 13630-13638.

(80) Kang, L.; Xing, Z. Y.; Ma, X. Y.; Liu, Y. T.; Zhang, Y. A Highly Selective Colorimetric and Fluorescent Turn-on Chemosensor for $\mathrm{Al} 3+$ Based on Naphthalimide Derivative. Spectrochim. Acta - Part A Mol. Biomol. Spectrosc. 2016, 167, 59-65.

(81) Basu, G.; Kubasik, M.; Anglos, D.; Secor, B.; Kuki, A. LongRange Electronic Interactions in Peptides: The Remote Heavy Atom Effect. J. Am. Chem. Soc. 1990, 112 (25), 94109411.

(82) Mullaney, B. R.; Thompson, A. L.; Beer, P. D. An All-Halogen Bonding Rotaxane for Selective Sensing of Halides in Aqueous Media. Angew. Chem. Int. Ed. 2014, 53 (43), 1145811462.

(83) Zapata, F.; Caballero, A.; Molina, P.; Alkorta, I.; Elguero, J. 
Open Bis(Triazolium) Structural Motifs as a Benchmark to Study Combined Hydrogen- and Halogen-Bonding Interactions in Oxoanion Recognition Processes. J. Org. Chem. 2014, 79 (15), 6959-6969.

(84) Mei, J.; Leung, N. L. C.; Kwok, R. T. K.; Lam, J. W. Y.; Tang, B. Z Aggregation-Induced Emission: Together We Shine, United We Soar! Chem. Rev. 2015, 115 (21), 11718-11940. 


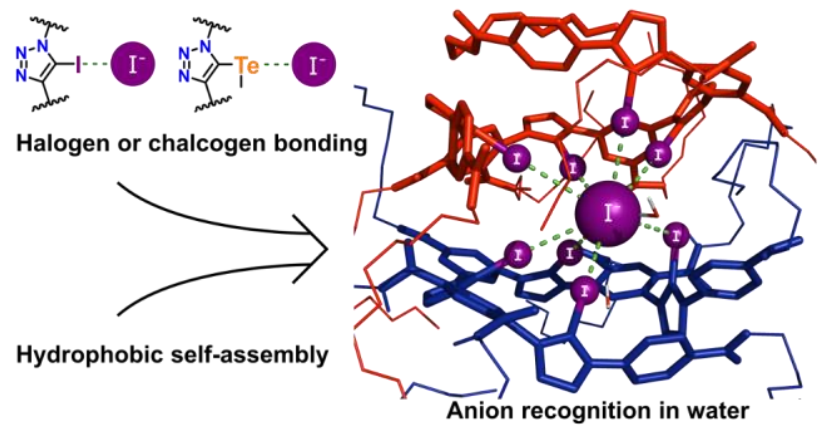

13 